\title{
Os impasses com o catolicismo negro vivido por rezadores em Santo Antônio de Jesus-BA (1940-1970)*
}

\section{Deadlocks with black Catholicism lived for rezadores in Santo Antonio de Jesus, Bahia (1940-1970)}

Manuela Santana Nascimento ${ }^{1}$

\section{Resumo}

Este artigo tem como objetivo discutir os impasses entre a Igreja católica e o catolicismo vivido por rezadores e rezadeiras do município de Santo Antônio de Jesus. Localizada no Recôncavo Sul da Bahia, a cidade entre as décadas de 1940 e 1970, recebeu uma grande quantidade de migrantes que abandonaram a decadência do campo e foram em busca de uma vida melhor na cidade. Esses sujeitos, que tiveram suas trajetórias marcadas por lutas e resistências trouxeram para a cidade os saberes de cura, ligados às culturas africanas e indígenas formadoras da cultura religiosa brasileira. São essas práticas que, mesmo com as mudanças da Igreja Católica ao longo do século XX, continuaram a ser marginalizadas no imaginário social que foram analisadas ao longo desse artigo. Para isso, foram utilizadas fontes orais e documentos eclesiásticos que direcionaram a compreensão do contexto sócio-histórico do período.

Palavras-chave: Populações negras. Práticas de cura. Catolicismo.

\section{Abstract}

This article aims to discuss deadlocks between the Catholic Church and Catholicism lived for rezadores and mourners of the municipality of Santo Antônio de Jesus. Located in the Recôncavo Southern Bahia, the city between the 1940s and 1970s, received a lot of migrants who have left the decay of the field and were in search of a better life in the city. These guys, who had their careers marked by struggles and resistances brought to the city the healing practices, linked to African cultures and indigenous forming the Brazilian religious culture. These are practices which, even with the changes of the Catholic Church in the twentieth century, continued to be marginalized in the social imaginary that were analyzed in this article. For that, oral sources were used and ecclesiastical documents that guided the understanding of the socio-historical context of the period.

Keywords: Black populations. Curing practices. Catholicism.

Recebido em: 07/07/2014 Aprovado em: 20/08/2014

1 Mestre em História Regional e Local pela Universidade do Estado da Bahia (UNEB), Departamento de Ciências Humanas - Campus V, esse artigo é resultado da minha dissertação de mestrado defendida em 2012, que contou com o financiamento da CAPES. 


\section{Introdução}

Os indicadores demográficos brasileiros, do período que compreende a década de 1940 a 1970, revelam que o Brasil, em sua maioria, era um país de católicos. O censo de 1940 estimava que 95,01\% da população era católica romana, 2,61\% declaravam-se protestantes, $1,12 \%$ espíritas e os outros $1,26 \%$ faziam parte dos que se declaravam de outra religião, sem religião ou sem declaração. Na década de 1970, os indicadores mantêm essa tendência e indicam que 91,77\% da população brasileira professavam o catolicismo².

Observando-se esses dados do censo, alguns questionamentos surgem frente à diversidade religiosa brasileira. Não há referência, nas estatísticas, às religiões de matrizes africanas e seria muita ingenuidade acreditar que elas não eram praticadas no país em meados do século XX. Onde o povo de Santo estaria agrupado? Fariam parte do grupo "outras religiões" ou "de religião não declarada"? Ou estariam inseridos no grande grupo de católicos do país? Seria a afirmação de pertencimento ao catolicismo uma estratégia de rezadores, benzedores e curandeiros para terem suas crenças "legitimadas" perante a sociedade racista?

As estratégias e astúcias do povo negro católico no Brasil ajudaram a montar arranjos de crenças, capazes de manter o equilíbrio espiritual dos indivíduos e deixar vivas as tradições religiosas que sobreviveram mesmo frente às constantes tentativas de marginalização e negação das práticas afro-ancestrais, reinventadas nas Américas.

Se os números revelam uma maioria de católicos no país, eles também ocultam as diversas formas de professar o catolicismo e as estratégias encontradas por brasileiros e afro-brasileiros, de viver numa conjuntura múltipla de religiosidades. Voltando-nos para as trajetórias de rezadores e rezadeiras da cidade de Santo Antônio de Jesus, e suas formas de crer, podemos perceber outros modelos de cristandade, discriminadas pela instituição Igreja, e por parte da sociedade marcada por preconceitos e hierarquias de crenças.

Localizada no Recôncavo Sul da Bahia, a 187 km da capital do Estado, Santo Antônio que, segundo os dados do Censo/IBGE de 2010, possui cerca de 90.949 habitantes, sendo desse total mais de $87,15 \%$ vivem no

2 IBGE. Portal do IBGE. Disponível em: < http://www.ibge. gov.br/seculoxx/arquivos_pdf/populacao/1982/populacao_m_1982aeb_044.pdf>. Acesso em: 27 out. 2011. perímetro urbano e $12,84 \%$ na zona rural $^{3}$, até a década de 1950 possuía um cenário inverso, no qual 60,10\% do seu contingente populacional residia nas áreas rurais do município (SANTOS, 2005, p. 47). Com o crescente fluxo, migratório que começa a reformular as populações das cidades do interior baiano nos anos de 1960, 1970 e 1980, inúmeras famílias de rendeiros, posseiros e lavradores, fugindo da decadência e das crises da agricultura no campo, passam a morar na cidade e continuam a seguir suas trajetórias, desenvolvendo suas sabedorias, seus modos de viver e de professar o catolicismo.

\section{A igreja católica e os conflitos com as mani- festações de fé}

Quando tratamos das manifestações de fé no Brasil, não podemos deixar de retomar a forma como a Igreja Católica lidou com as outras religiões no país desde o período colonial. É certo que as tentativas de eliminar, sobretudo, as práticas religiosas africanas ligadas aos processos de cura e alcance de graça temporal do território brasileiro resultaram num grande fracasso; no entanto, mesmo frente à larga utilização e comprovação de eficácia - inclusive entre os brancos na Colônia - a Igreja Católica conseguiu "marginalizar, criminalizar e exorcizar as práticas religiosas africanas", reforçando os estereótipos depreciativos e que as colocavam como elementos primitivos. (SWEET, 2007, p. 256)

Entretanto, as posturas da Igreja revelam uma contrapartida interessante e percebida com bastante sensatez pelo historiador James Sweet. Ironicamente, era a Igreja Católica a principal retificadora do poder espiritual dos africanos escravizados ou libertos ao tentar desenfreadamente erradicar as práticas “pagãs' como a 'idolatria', o 'feitichismo' e a 'feitiçaria”'. (SWEET, 2007, p. 270). Nesse processo, como destaca Sweet, a Igreja acabava por dar

mais fulgor a estas forças espirituais alternativas e contra-hegemônicas - em especial no seio da comunidade branca. Comportamentos africanos que poderiam ser simplesmente ignorados como uma manifestação de superstição eram transformados numa realidade que desafiava os preceitos do Catolicismo e da ordem social alargada. (SWEET, 2007, p. 271)

3 Dados encontrados em: IBGE. Portal do IBGE. Disponível em: <http://www.ibge.gov.br/home/estatistica/populacao/ censo2010/tabelas_pdf/total_populacao_bahia.pdf $>$. Acesso em: 07 mar. 2012 
Essa perseguição constatada durante o período colonial não vai se esgotar no século XX. A Igreja continuará a condenar as outras manifestações de fé, principalmente quando estas estão presentes em rituais aparentemente católicos. Por que tanto receio de manifestações de fé feitas por sujeitos "iletrados"? Seria por conta da cosmovisão africana ter penetrado nos meandros da formação espiritual e religiosa dos brasileiros?

No Brasil, a Igreja que chegou legitimando a ação colonizadora, inserida na máquina administrativa, levou à demonização de qualquer outra forma de crer existente e as que se desenvolveram fora do padrão euro-católico-ocidental. Por maiores que fossem as imposições da instituição, a fé costuma a pairar sobre todos os outros valores, e os arranjos do catolicismo coexistiram mesmo com as tentativas constantes de sua extinção (MAINWARING, 1989, p. 15-16).

Mesmo frente a um ambiente hostil, de perseguição e punição dos que não seguissem a cartilha da Igreja, é preciso atentar para as formas de expressão das experiências africanas sobre o véu do cristianismo. Para Sweet, a "aceitação do catolicismo entre os africanos foi lenta desigual, e mesmo quando parecem registrar-se manifestações da fé cristã, continuam a poder ser encontrados elementos do passado religioso africano em coexistência com as práticas cristãs". (SWEET, 2007, p. 225)

Esse duplo pertencimento não causava estranheza aos africanos trazidos para o Brasil. Segundo o mesmo autor, não foram os elementos e as formas de crer e de curar africanas que sobreviveram pontualmente no país; houve, antes de tudo, uma transferência da mundividência africana para o Brasil e por conta dessas formas de compreensão do mundo temporal e espiritual é que foi possível recriar no território brasileiro as práticas afro-ancestrais. (SWEET, 2007, p. 267). Por conta disso, as tentativas de padronização da fé não surtiram o efeito desejado; e as estratégias de conversão e controle da Igreja, alteradas ao longo dos séculos, mantiveram a depreciação às expressões negras da religião, tentando desqualificar os rezadores, rezadeiras, beatos, movimentos messiânicos, criando grupos de leigos, novas dioceses, congressos catequéticos e tudo mais que servisse para reforçar sua autoridade. $^{4}$

4 A partir da década de 1940, a Igreja Católica tomou uma série de medidas para ajudar a solucionar os "problemas" com a fé católica, que sempre causou constrangimentos ao
Não podemos negar que o século XX foi marcado por muitas inconstâncias e mudanças de perspectivas da Igreja com relação, principalmente, às causas sociais. Se até o século antecessor a Igreja atuou junto às elites e, mesmo com a romanização e suas fortes tentativas, não conseguiu padronizar e controlar as práticas religiosas do povo, vistas como uma expressão da ignorância e da superficialidade da fé até a década de 1930, a partir da década de 1940, uma atenção maior começou a ser dada a esse povo por meio das ações catequéticas e da educação religiosa feita por clérigos e por leigos preocupados ainda com a "ignorância" religiosa popular. (MAINWARING, 1989, p. 51)

Até a década de 1950, a ideia predominante era de que o povo deveria aprender a crer e abandonar as deficiências religiosas com a ajuda do clero. Havia uma hierarquia estruturada no princípio paternalista de que o padre, uma figura de caráter e postura mais elevada, deveria conduzir o povo à elevação de sua fé. No entanto, a conjuntura social e política que envolvia o mundo pós-guerra, a expansão das ideias comunistas (no Brasil o fim da ditadura do Estado Novo (1930-1945); a intensa movimentação política que envolvia os setores organizados da sociedade, como os trabalhadores rurais no Nordeste, organizando suas lutas e interesses no intervalo democrático, interrompido com o golpe militar de 1964, interferiram também na ação dos grupos pastorais, formados por leigos e clérigos. Além disso, a Igreja no país passou a seguir os novos rumos traçados a partir do Concílio Vaticano II (1962-1965) ${ }^{5}$.

clero local, vivida pelos baianos. A escassez de padres, de instituições que assumissem a catequese e uma população com práticas religiosas não exclusivamente católicas exigiu da Igreja medidas para fortalecer a instituição no Estado. Além dos Congressos Catequéticos, que funcionavam como um espaço de diálogo para o aperfeiçoamento da catequese dos baianos, novas Dioceses foram criadas, entre elas a de Amargosa em 1942, à qual a cidade de Santo Antônio passou a ser vinculada. Com um bispado mais próximo, a Igreja conseguia ser uma presença mais constante para a população do interior do Estado, embora isso não tenha implicado, necessariamente, numa mudança de postura das formas de crer e professar o catolicismo entre a população. Ver mais em: NASCIMENTO, Manuela Santana. A lei deles é uma, a do povo é outra: experiência e impasses com o catolicismo vivido por rezadores em Santo Antônio de Jesus-BA (19401970). 2012. 124 f. Dissertação (Mestrado) - Programa de pós-graduação em História Regional e Local, UNEB, Santo Antônio de Jesus-Bahia, 2012.

5 Sobre o intervalo democrático e as lutas sociais feitas no Brasil ver: FERREIRA, J.; DELGADO, Lucilia de A. N. (Org.) $O$ Brasil republicano: o tempo da experiência democrática: da 
Esse Concílio, frente à pressão social que ecoava nos novos tempos, foi um dos responsáveis pelo processo de renovação institucional da Igreja, quando já tinha estreitado ligações com as causas dos menos favorecidos. $\mathrm{O}$ aval de Roma ajudou a desenvolver a noção de "Igreja como o povo de Deus", valorizando o diálogo com outras religiões, tornado a liturgia mais acessível, firmando compromisso com as causas sociais. (MAINWARING, 1989, p. 62)

A partir do Concílio, o diálogo com as religiões não cristãs passou a ser valorizado e os grupos mais progressistas da Igreja passaram a rejeitar "qualquer discriminação ou perseguição, feitas a homens por causa de raça ou cor, posição ou religião.” Nesse sentido, ela começou a reconhecer o valor das diferentes crenças e reconhecer que o diálogo "ecumênico não deve significar, necessariamente, indiferença na procura da verdade de Deus, mas implica, precisamente, maior atenção pela verdade que nos une [...]"6. Foi uma espécie de reconhecimento da humanidade e da irmandade com o outro.

A renovação e o repensar de práticas foi o que moveu a mudança de postura da instituição, iniciada nas bases com os grupos de leigos e clérigos progressistas que atuaram junto aos jovens, operários e trabalhadores rurais e que fizeram da Igreja do Brasil uma das mais progressistas da América Latina. Assumir-se como o "povo de Deus" aproximava a Igreja dos seus fiéis que passavam a ser a causa da instituição. Beozzo destaca que “a noção de "igreja dos pobres" conotava os deserdados da história, os sem voz e sem vez, tomando como sujeitos históricos os indígenas, os escravos africanos, mulheres, camponeses sem terra, classe operária, os marginalizados e excluídos com sua expressão religiosa”. (BEOZZO, 2001, p. 375-376)

Lutar pelos pobres e marginalizados, estar ao lado dos que sofrem, e não acima, foi uma mudança de perspectiva significativa na vida dos católicos e na concepção religiosa dos indivíduos, pelo menos daqueles que faziam parte das alas mais progressistas da Igreja Católica. Assumir a causa dos oprimidos, ser a voz dos que sofrem e não são ouvidos teve uma importância simbólica muito gran-

democratização de 1945 ao golpe civil-militar de 1964. Rio de Janeiro: Civilização Brasileira, 2003.

6 BIBLIOTECA PÚBLICA DO ESTADO DA BAHIA (BPEB). O Nôvo Catecismo: fé para adultos. Obra redigida pelo Instituto Catequético Superior de Nijmegen, em colaboração com diversos, e por ordem dos Senhores Bispos da Holanda. São Paulo: Loyola, 1974. p. 267-270. de na relação estabelecida entre os sujeitos e a Igreja. Essa postura eclesiástica influiu, sem dúvida, na forma como a lei da Igreja passou a ser vista e interpretada pela lei do povo. Por mais que a necessidade de acolher e vigiar os catolicismos possa ter permanecido em muitos setores da instituição católica, as manifestações de fé e religião dos sujeitos continuaram dando prova do seu caráter escorregadio, inventivo e múltiplo.

Até o período em que as causas sociais e luta junto aos desfavorecidos, frente às injustiças presentes no mundo, não eram causas da Igreja é relativamente fácil visualizar os conflitos e a busca de uma "fé purificada" e distante das coisas do mundo, norteando os interesses e ações da instituição. No entanto, quando essa conjuntura começa a dar sinais de mudança e as causas dos socialmente oprimidos passam a ser bandeira das alas progressistas da Igreja, é muito mais complicado perceber o limite entre a aceitação e o combate das formas de crer do povo.

$\mathrm{Na}$ conjuntura de mudanças provocadas a partir de meados do século XX, os interesses de agregar e vigiar devem ser vistos sobre a mesma perspectiva múltipla que desenha as formas de ser católico dos indivíduos. As interpretações da religião, feitas por rezadores e rezadeiras, contam com a incorporação e a formação de novos sentidos respaldados no novo perfil agregacionista da Igreja. Ou seja, se eles são o "povo de Deus e da Igreja”, as suas práticas de cura e seus os catolicismos também são.

\section{A Fé dos que benzem na cidade}

Por mais que as mudanças provocadas pela abertura da Igreja no século XX tenham gerado uma aproximação com as causas sociais e estabelecido um diálogo com outras religiões, a presença das religiões afro-ancestrais e suas práticas continuaram a gerar problemas de incompreensão e intolerância. Na cidade de Santo Antônio de Jesus, o diálogo entre as religiões e com a forma de professar o catolicismo dos rezadores nem sempre foi feito de maneira respeitosa.

A Igreja Católica não é e nem foi uma instituição una. Grupos progressistas conviveram com conservadores e estabeleceram diálogos de proximidade ou repulsa aos catolicismos vividos pelos indivíduos, e as novas diretrizes da instituição permitiram uma aproximação ainda maior com práticas consideradas "menos ortodoxas".

Em Santo Antônio de Jesus, as relações também tiveram esse caráter múltiplo. Desde década de 1940, a 
Paróquia da cidade estava estruturada com quatro igrejas: a Matriz e a de São Benedito ${ }^{7}$; a igreja de São José e uma capela na Vargem Grande ${ }^{8}$; nove centros paroquiais, onde se ministrava a catequese para crianças e adultos; e cinco grupos organizados de leigos que ajudavam na tarefa evangelizadora ${ }^{9}$.

Nas reuniões com os grupos de leigos e os padres, era comum que os participantes dessem um testemunho sobre sua fé. Como relatou o padre José Raimundo dos Santos, filho da rezadeira Jacinta dos Santos ${ }^{10}$, a opção preferencial pelos pobres da Igreja na América Latina resultou numa aproximação com "a sabedoria, o modo de ver o mundo, de se relacionar, de solucionar" os problemas, numa "atitude aberta e segura de que há muito o que aprender." Grupos pastorais nasceram dessa iniciativa de olhar o outro "como um todo relacionado ao ambiente, à sociedade, à prática da fé; e a Igreja pôs-se à escuta da gente simples e de suas práticas, descobrindo seus remédios, suas rezas." 11 Em um desse círculos, o rezador Crispim dos Santos contou que já deu o testemunho de sua missão no mun-

7 As mais antigas igrejas da cidade, criadas ainda no século XIX. LIVRO do Tombo da paróquia de Santo Antônio de Jesus. Arquivo Eclesiástico da Paróquia de Santo Antônio de Jesus (AEPSAJ), Santo Antônio de Jesus, Bahia, Brasil, p. 46.

8 Vargem Grande, atual Varzedo, era um distrito que pertenceu, até 1989, a Santo Antônio, quando conseguiu sua emancipação política. Ver: JESUS, Elmo Manuel de. Emancipação municipal: uma estratégia para o desenvolvimento local? - o caso de Varzedo-Ba. 2008. 153 f. Dissertação (Mestrado) Programa de Pós-graduação em Cultura, Memória e Desenvolvimento Regional, UNEB, Santo Antônio de Jesus-Bahia, 2008. p. 16.

9 Consta no Livro do Tombo da Paróquia de Santo Antônio de Jesus que os centros paroquiais estavam distribuídos entre a igreja Matriz nos bairros e ruas do São Benedito, Andaiá, Cancela, Cajueiro, Calabar e Queimada e mais dois no distrito de Vargem Grande. (p. 46). Já os grupos de leigos da cidade estavam divididos entre o Apostolado da Oração, a Confraria do Rosário, a Ação Católica, a Congregação Mariana de Moças e Moços e a Cruzada Eucarística Infantil. (p. 52)

10 A rezadeira Jacinta dos Santos de 82 anos natural de Gandú migrou para Santo Antônio em 1969.Entrevista em 18 jun. 2010.

11 Padre José Raimundo dos Santos, entrevista concedida em 01 jun. 2011. Natural de Santo Antônio de Jesus, José Raimundo nasceu em 1970 e foi ordenado padre em 1995. Atuou em paróquias da região como Conceição do Almeida, Amargosa, Milagres, São Miguel das Matas e Nilo Peçanha. Foi pároco por mais de cinco anos da Comunidade de Língua Portuguesa de Wiesbaden e da Diocese de Limburg em Frankfurt na Alemanha e atualmente vive em Roma, no Pontifício Colégio Pio Brasileiro realizando estudos de Mestrado em Teologia e Ciências Patrísticas no Instituto Patrístico Agostiniano da Pontifícia Universidade Lateranense. do a pedido do padre que coordenava o grupo e disse que sua missão era "rezar as pessoa, com o poder de Deus!":

Aliviar uma dor de cabeça, dor de dente, cortar uma dor, atrapalhação de quem esteje na família, usura, inveja... Entendeu? A vezes a pessoa tá no hospital, chega do hospital, pede pra eu ir rezar, ai eu vou recebo com os poderes de Deus. Se tiver fé em Deus e acreditar no que venha ver alcançar Deus cura! E ai eu boto as pessoas nas orações, rezo com a luz. ${ }^{12}$

A reza tomada como missão para Crispim e compartilhada entre os participantes da reunião nem sempre é interpretada de maneira positiva por outros católicos. Silvino Francisco dos Santos, que conviveu durante a infância com as rezas feitas por sua mãe, tem opinião divergente quanto à eficácia e o valor das curas realizadas por rezadores e rezadeiras. Para Silvino, o caminho das rezas é um terreno duvidoso que, mesmo não sendo proibido pelos padres, não deve ser algo com tanto valor. Para ele, "tem gente que tem o poder de curar... Agora, depende da fé!”. Ele contou que, certa vez, quando um de seus filhos estava doente, alguém o aconselhou a procurar uma rezadeira. Mesmo relutante, ele resolveu tentar, e ao encontrar a rezadeira ele questionou: “A senhora sabe rezar? A senhora sabe fazer o sinal da cruz?' Não sabia! 'A senhora já ensinou seu filho a fazer um sinal da cruz? 'Não sabe! Então, como reza assim?"13

Para Silvino, uma pessoa que não sabe fazer nem “o sinal da cruz" não pode ter credibilidade nos negócios da cura. A religião professada pelo sujeito contaria no momento de se atestar a eficácia e a validade da cura, já que, para ele, a reza só faria sentido se fosse feita por católicos.

Já a rezadeira Maria de Lurdes diz nunca ter ouvido na Igreja alguém falar nem contra, nem a favor de rezador. E nunca ouviu porque, segundo ela, "eles num pode falar, porque eles não sabe! E além de quê, se sou-

12 Crispim dos Santos, rezador, negro, 73 anos, entre muitas idas e vindas passou a morar em Santo Antônio de Jesus por volta da década de 1950. (in memorian). Depoimento cedido em 13 mai. 2011. Sobre a trajetória do rezador Crispim ver: NASCIMENTO, Manuela Santana. Devagar com esse negro mandingo: o catolicismo negro vivido por um rezador no Recôncavo Baiano (1940-1970). In: ANAIS ELETRÔNICOS DO XXVII SIMPÓSIO NACIONAL DE HISTÓRIA - ANPUH, 2013, Natal-RN. Disponível em: <http://www. snh2013.anpuh.org/resources/anais/27/1364949662_ARQUIVO_artigocompletoANPUH2013.pdf $>$. Acesso em: 11 jun. 2014.

13 Silvino Francisco dos Santos, 97 anos natural de São Miguel das Matas e morador de Santo Antônio de Jesus desde 1975 é negro e filho de rezadeira. Entrevista em 17 jun. 2010. 
besse não podia falar, que a lei deles é uma, e a do povo é outra!"14 Declarando-se católica, Lurdes é categórica ao afirmar a validade do seu dom e a diferença entre a "lei do povo" e a "lei da Igreja". E qual significado teria o catolicismo para esses rezadores?

Criticada por alguns católicos por fazer benzenções, Jacinta dos Santos contou que certa vez, foi questionada sobre o significado e a utilidade dos três ramos de folha no ritual da reza. E sua explicação para o significado do "três" foi à seguinte:

Tem tanta coisa que significa três! Oia! Faz parte das três pessoas da santíssima trindade: Pai, Filho e Espírito Santo. Três vem dos três dias com que Jesus foi ressuscitado! Quer dizer, que esse símbolo do ramo que a gente pega significa essas coisas todas! É isso, a gente se baseia nos três ramo verde... "Porquê? Mas...É... Não precisava!” Eu digo: Não precisava? Não! Se a gente crê e tem fé, precisa que tenha o ramo, o ramo verde... ${ }^{15}$

O ritual da reza de benzedura que envolve orações e a utilização de elementos capazes de afastar os males encontra respaldo em diversas explicações, segundo Jacinta. Essas explicações podem estar ligadas a preceitos católicos ou a conhecimentos e princípios de ancestralidade africana e indígena, como no caso da utilização da folha certa para cortar o mal ou na preparação de chás e beberagens. O que nos interessa com esse exemplo é a forma como os sujeitos se apropriam dos signos e formulam significados para as suas ações e práticas, de acordo com o universo em que vivem. E mais, Jacinta complementa sua fala sobre a eficácia de suas curas dizendo que "se não fosse assim, os médicos não mandava 'procure uma benzedeira que ajuda muito na cura do fogo selvagem ${ }^{16 "}$. Outro elemento aparece na sua fala: a apropriação por parte da medicina "oficial" dos saberes ancestrais para ajudar na cura das doenças.

Destaquei esses três personagens e as três formulações envolvendo a prática de cura e a religião, porque elas carregam interpretações formuladas com base em visões diferenciadas acerca do catolicismo. A argumentação de Silvino, vinculando à validade do dom em relação

14 Maria de Lurdes Silva, negra, rezadeira, 77 anos nasceu na localidade do Tabocal e migrou para Santo Antônio em 1945. Entrevistas em 14 ago. 2008/ 08 jun. 2010. Depoimento cedido em 14 ago. 2008.

15 Jacinta dos Santos, depoimento cedido em 18 jun. 2010

16 "Fogo selvagem - fogo de Santo Antônio = herpes zoster." (SANTOS, 2005, p. 212). à religião que pertence o rezador ou rezadeira, coaduna com a ideia de que a religião católica seria a única com validade e credibilidade perante os "homens de bem".

A visão maniqueísta de que práticas próximas ou legitimadas pelo catolicismo fariam parte do bem Deus -, e outras que não fossem explicadas pela Igreja teriam parte com o mal - o Diabo -, ressoou e permaneceu no imaginário coletivo desde os tempos da colonização. ${ }^{17} \mathrm{Na}$ empreitada colonizadora coube a indígenas e africanos fazerem as vezes do Diabo, seguindo a lógica europeia trazida com os portugueses. O pecado estaria nos selvagens indígenas e africanos que não conheciam o Deus, nem a civilização cristã. O papel das teorias evolucionistas e do racismo científico formulados no século XIX também contribuíram para o reforço das supostas inferioridades de forma institucionalizada e respaldada pela ciência ${ }^{18}$. Por mais execráveis que sejam essas teorias na atualidade, não devemos subestimar o poder que essas ideias tiveram, e ainda tem, de montar uma lógica cruel de inferiorização dos sujeitos e das culturas negras e indígenas, encontrando as maneiras mais violentas de continuar a reverberar suas elucubrações.

Os estereótipos depreciativos em torno dos africanos, afrodescendente e indígenas, junto com suas culturas e religiões, ecoaram e insistiram em permanecer na sociedade por conta de fatores há muito tempo conhecidos. A abertura a todas as confissões religiosas no início da República, o reconhecimento por parte da Igreja da diversidade de cultos e o diálogo ecumênico, já em meados do século $\mathrm{XX}$, não implicaram o respeito às religiões afro-brasileiras; mas, sim, na tentativa de silenciamento e exclusão dos que não se alinhavam aos dogmas. A formação religiosa desses sujeitos, que buscam reforçar o pertencimento ao catolicismo e a negação das religiões afrodescendentes, estão inseridas numa concepção que classificou as religiões em estágios que iam do mais ao menos evoluído. E a evolução, ligada, também, às tradi-

17 Sobre os medos disseminados na Europa e trazidos para as Américas com a colonização ver: SOUZA, Laura de Mello e. O diabo e a terra de Santa Cruz: feitiçaria e religiosidade popular no Brasil Colonial. São Paulo: Companhia das Letras, 1993.

18 Sobre o papel do racismo cientifico e sua contribuição para a formação da hegemonia euro-ocidental ver: SILVEIRA, Renato da. Os selvagens e a massa: papel do racismo científico na montagem da hegemonia ocidental. Afro-Ásia, Salvador, n. 23, 1999. Disponível em: <http://www.afroasia.ufba.br/ pdf/afroasia_n23_p89.pdf $>$. Acesso em: 11 jun 2014. 
ções de um catolicismo romanizado que não foi completamente anulado com os novos ventos católicos no país, buscou, em variados graus, demonizar e extirpar da sociedade qualquer traço religioso não cristão.

O imaginário depreciativo formado em torno do Candomblé, da Umbanda e de outras religiões de matrizes africanas permanece forte na memória de muitos rezadores e rezadeiras, que tenderam a caracterizar essas religiões como negativas. Pesquisadores das práticas afro-ancestrais no Brasil têm mostrado como a construção de um imaginário negativo foi largamente reforçado pelos discursos da imprensa, da polícia, das autoridades políticas e eclesiásticas desde o período colonial. O Império e a República não se mostraram muito diferentes e, até meados do século passado, ainda não era possível notar tantas mudanças.

As práticas afro-religiosas, além de serem consideradas um desvio da fé, foram classificadas como um problema de saúde pública. Pesquisas, como a de Josivaldo Pires atentaram para a forma como a perseguição à religião se fez presente sobre outros contornos, mesmo quando a multiplicidade de cultos já era permitida no Brasil. (PIRES, 2010, p. 40) O cuidado para não se deixar ludibriar pela esperteza dos "charlatães" foi bem enfatizado na fala do padre Nelson Franca, que atua na paróquia de Santo Antônio a mais de trinta anos. Segundo ele, a Igreja que, olha com respeito a ação dos rezadores e benzedores, não é a dona "dos dons e carismas! É o Espírito de Deus. Tudo é gratuidade de Deus!" Entretanto, ele afirma:

Na medida em que agente respeita, nós não estamos já confirmando que aquilo é real, que aquilo é verdadeiro, que aquilo é puro. Já é o segundo aspecto, e esse segundo aspecto nos faz atentos, cuidadosos e reticentes aos chamados "espertalhões" que fazem a exploração da chamada boa fé. O verdadeiro rezador, benzedor é aquele que, diante de quem o busca, dá o testemunho da sua fé. Então, ele age, atua através da sua oração, diante da outra pessoa que o busca porque ele crê. ${ }^{19}$

O cuidado com os "espertalhões" que deixa, segundo o padre, a Igreja reticente, ocorre porque "nem sempre tudo que aí está é fruto da fé!" Para ele,

Muitos fazem desta prática da cura, da oração uma forma de sobrevivência e, num país de pobres e consequentemente num país de doentes, são muitos os que buscam a cura e são outros tantos que exploram da enfermidade, da doença e da miséria do outro dizendo-se capazes de curar e, aí curam pela troca do dinheiro.

19 Padre Nelson Franca, depoimento cedido em 22 ago. 2008.
A validade do carisma estaria na sua distribuição de maneira gratuita e a cobrança seria sinal da má fé dos que dizem curar. É certo que não devem ter sido poucos os episódios com sujeitos que, por métodos escusos, pretenderam curar e fazer disso um meio de vida na sociedade. Mas as práticas de cura tratadas e problematizadas neste artigo dizem respeito aos saberes transmitidos na oralidade por meio de gerações e que, por vezes, podem ser reforçados pela interseção de um banho com ervas ou com a utilização de outros materiais que precisam ser comprados pelo rezador.

A cobrança pelo serviço, como também abordou o historiador Denílson Santos, não significava que o rezador se configurasse num "charlatão". Alguns trabalhos como, por exemplo, "limpeza de corpo, um arreio de ebó $^{20}$ ou qualquer outro procedimento mais complexo" exigiam a compra de materiais de custo elevado para a realização da cura, o que tornava necessária a cobrança do serviço. (SANTOS, 2005, p. 111)

Dois dos rezadores que entrevistei cobravam por seus serviços e dentre eles estava Crispim dos Santos, que mantinha ao lado do altar de sua casa uma tabela com os preços dos serviços que costumava prestar. Crispim afirmava, com contundência, que não cobrava pela palavra de Deus. "A palavra de Deus eu não vendo! Aí, as pessoa vem aqui, reza, quando termina de rezar, bota cinco, bota dez; aí, eu compro o quilo de farinha, compro a vela do santo, uma bolacha, um pão, pra eu tomar café..."

Figura 1 - Altar da casa de Crispim dos Santos

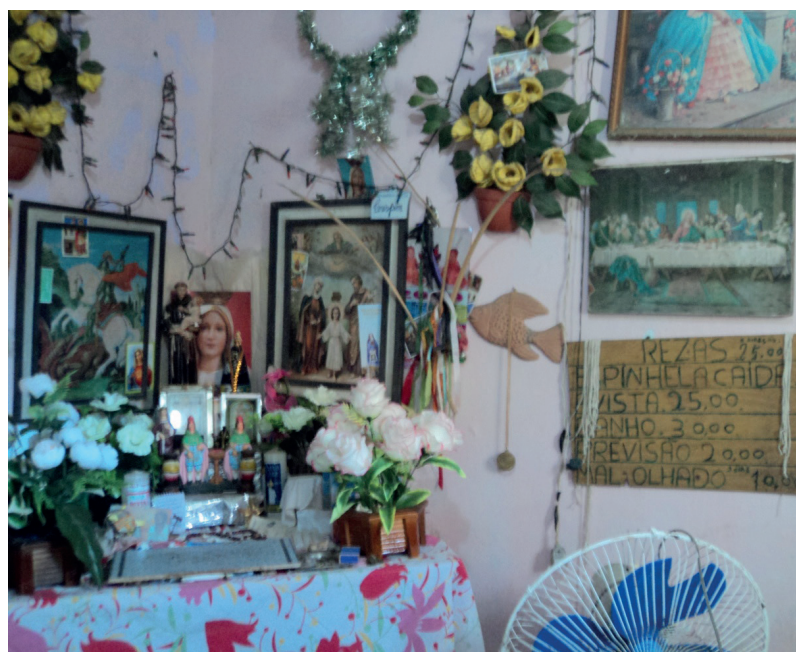

Fonte: NASCIMENTO, Manuela Santana, 2011. 1 fotografia digital.

20 Arreio de ebó - Realizar uma oferenda aos deuses. (SANTOS, 2005, p. 211) 
As cobranças feitas pelo rezador justificavam-se por todo material que ele utilizava no ritual de reza, como velas, ingredientes para o preparo dos banhos como frascos de alfazema, plantas de origens variadas, dentre outros materiais que precisavam ser comprados. Era com o dinheiro das rezas que Crispim arrumava o altar da casa, comprava os materiais de trabalho, conseguia fazer suas romarias à Bom Jesus da Lapa e trazer águas-bentas e outros elementos necessários para o fortalecimento de sua fé e sabedoria.

Inconciliáveis com a modernidade, incompatíveis com o que foi considerado religião, recebendo o estigma do charlatanismo, os costumes afro-católicos tiveram que encontrar formas de manifestação e de afirmação perante a rejeição social que se lhes impunham. Os caminhos da fé e da cura, para a rezadeira Maria de Lurdes, não precisavam de justificativa e legitimação de uma lei que não permitia práticas que fogem dos padrões explicativos de uma instituição. "A lei deles é uma, a do povo é outra!" $\mathrm{O}$ modo de agir frente às leis da Igreja é reflexo da forma que a rezadeira encontrou de afirmar suas crenças por meio de outro universo de significações.

Por mais que afirmar-se católico, associar a trajetória de vida ao catolicismo, tenha sido para muitos uma estratégia encontrada para conviver melhor com as lembranças pessoais, as reformulações, tanto do catolicismo quanto das tradições afrodescendentes, ocorreram e imprimiram novas formas de leitura dos símbolos que atuam no imaginário social.

Uma vez presente na diversidade social, o controle dos valores, culturas e religiões se perdem (ou se encontram) nas incorporações e nas múltiplas identidades que formam os sujeitos. $\mathrm{O}$ que acontece com as atitudes de Lurdes em relação a seu dom e à religião, ou entre Jacinta e suas explicações acerca dos elementos de cura é aquilo que Édouard Glissant classificou como os choques irremissíveis entre as culturas que provocaram trocas e transformações sociais com um grau altíssimo de imprevisibilidade. O imprevisível tomou conta das culturas formadas baseadas em contatos entre mundos distintos que tentaram (e ainda tentam) conviver em sistemas sociais que tenderam a acreditar numa identidade única dos sujeitos. E mais, a inferiorização e desvalorização das heranças culturais das matrizes afro-indígenas, pelas tradições euro-ocidentais, ajudaram a negligenciar e reduzir a importância desses elementos na formação social, cultural e religiosa do Brasil.(GLISSANT, 2005, p. 18)
Viver num duplo espaço de crenças é comum para muitos sujeitos, a rezadeira Almerinda Muniz, quando indagada sobre a sua religiosidade, afirma ser católica, mas, também, ser da Umbanda e possuir em sua casa dois altares: um com imagens de Nossa Senhora Aparecida, Bom Jesus da Lapa, Santo Expedito, e um quadro com Iemanjá na entrada da casa; e outro, - que ela considera ser o centro de sua reza -, com mais imagens de Iemanjá, do Caboclo Boiadeiro, da Jurema. Curiosamente, a imagem de Iemanjá aparece nos dois espaços de devoção da casa, além delas, imagens de santos também enfeitam as paredes da casa, dentre outras imagens e elementos religiosos espalhados pelos cômodos, testemunham a fé da dona da casa. ${ }^{21}$

Figura 2 - Altar da entrada da casa de Almerinda Muniz da Paixão

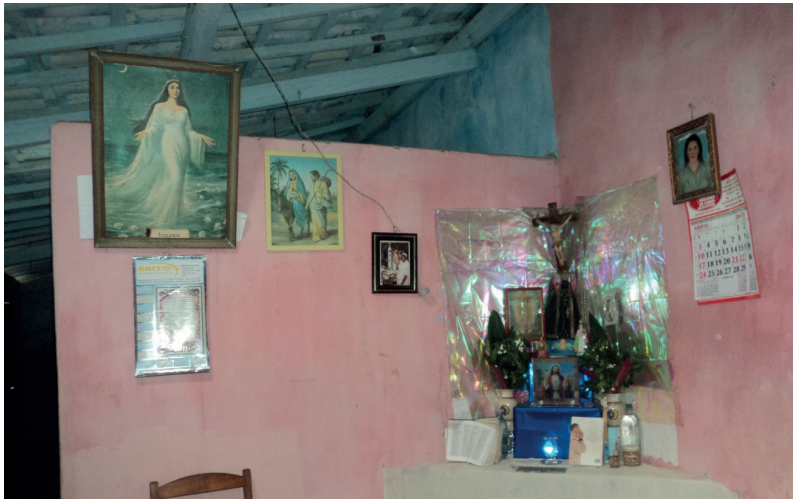

Fonte: NASCIMENTO, Manuela Santana., 2011. 1 fotografia digital.

A coexistência dos dois altares e a singular decoração da casa de Almerinda são, também, flagrantes da forma singular de revelação das experiências religiosas de muitas outras rezadeiras em um determinado espaço. Como discute Denílson Santos, a forma original como se estabeleceu essa dupla pertença religiosa, consiste

[...] no fato de muitas pessoas terem experimentado, como diria Muniz Sodré, uma "estrutura dupla, em ter jogado com as ambiguidades do poder e, assim, podido implantar instituições paralelas". Conviver e experimentar duas ou mais formas de práticas religiosas, implicaria (não necessariamente para todos os casos) em mais adiante (re)elaborar outros significados

21 Não fui autorizada a fotografar o altar de Umbanda que fica nos fundos da casa da rezadeira, fotografei, apenas, o altar "católico", que fica na sala principal da casa. Almerinda Muniz da Paixão 57 anos nasceu em 1955, na Mina da Pedra Preta e migrou para Santo Antônio em 1974. Mulher negra afirma ser católica e da umbanda. Entrevistas em 18 ago. 2008/ 07 nov. 2011 
religiosos a partir da junção ou diferenciação de uma cultura em relação a outra. (SANTOS, 2005, p. 115-116)

A estratégia de duplo pertencimento diferenciou as experiências religiosas que foram - e ainda são - vistas por muitos como um processo de "aculturação" ou como "sincretismo". Tais conceitos, além de limitarem a participação do sujeito no processo de formação, preveem sobreposições de elementos que foram formados por meio de trocas culturais. Como discute Peter Burke, o termo “aculturação" pressupõe uma alteração completa de um elemento cultural, que não se percebe no caso da demonstração de fé calcada em duas práticas religiosas distintas, conforme podemos inferir dos altares encontrados na casa da rezadeira Almerinda, bem como nas suas falas. (BURKE, 2006, p. 47) Ela afirma ser católica batizada e crismada (graças a seu "Bom Deus!"), da mesma forma que afirma ser o culto a Iemanjá, “a moça que [lhe] domina”, o centro de sua reza ${ }^{22}$.

As análises acerca dessa relação cindida das populações negras nem sempre partiram de referenciais lúcidos e adequados para compreender tal relação; por conta disso, diversas teorias cheias de limitações foram formuladas. Um desses conceitos foi o do "sincretismo" que apresenta de forma simplista as estratégias de resistência cultural e inserção de novos paradigmas religiosos pelos africanos e seus descendentes. Conforme analisa Gabriela Sampaio, o termo sincretismo, interpretado de diversas formas, foi tomado como uma espécie de "amálgama, mistura de elementos de diferentes origens culturais, no sentido de uma união artificial de ideias disparatadas, uma fusão de elementos antagônicos, o que acabaria gerando uma 'promiscuidade' cultural” (SAMPAIO, 2000, p. 230). Essa interpretação, carregada de juízos de valor, pressupõe uma relação hierarquizante tomando uma cultura como mais civilizada do que a outra, dando a entender que a "degeneração" de uma se dá pela "contaminação" da outra considerada inferior.

Outra interpretação do termo sincretismo pressupunha uma falsidade dos africanos e seus descendentes, que no processo de conversão "fingiam" uma aproximação com o catolicismo, praticando "um grande cinismo cultural" (SAMPAIO, 2000, p. 231). Os estudos de Nina Rodrigues, no final do século XIX, e de seus discípulos

22 Almerinda Muniz da Paixão, depoimento cedido em 18 ago.2008. do século XX, direcionaram o conceito de sincretismo para a "ilusão de catequese", limitando a interpretação do catolicismo pelas populações negras apenas à associação entre santos e orixás.

Pioneiro nos estudos sobre a religião dos negros e africanos no Brasil, o médico legista Raimundo Nina Rodrigues, envolvido pelos ideais evolucionistas do seu tempo, defendeu a tese de que os africanos e negros do país teriam uma capacidade intelectual muito baixa, o que comprometia a compreensão da religião católica por essa população. Dessa forma, as práticas católicas desenvolvidas pelo povo brasileiro estariam divididas entre quatro formas: um monoteísmo católico, que se era "por poucos compreendido, por menos ainda [era] sentido e praticado"; a "idolatria e mitologia católica dos santos profissionais", que teria uma grande variedade de praticantes entre eles brancos, mestiços e negros mais inteligentes; o sincretismo, que seria a forma de conversão cristã dos negros e resultava na associação dos orixás africanos aos santos católicos; e, por fim, as práticas fetichistas estreitas dos inconvertíveis "africanos das tribos mais atrasadas, dos índios, dos negros crioulos e dos mestiços do mesmo nível intelectual” (RODRIGUES, 1988, p. 215-216). Rodrigues acreditava que o baixo grau de abstração dos africanos permitia uma compreensão religiosa limitada conseguida só com a associação a coisas concretas da natureza, não sendo capazes de apreender a onipotência e a onisciência de um Deus único.

Divulgador e continuador da obra de Nina Rodrigues, Artur Ramos, que também foi médico legista e professor de antropologia, dedicou-se, por volta dos anos de 1930, a examinar o sincretismo religioso dos negros brasileiros. Em suas análises sobre o sincretismo, Ramos acreditava que aquilo que Rodrigues avaliou ser a "ilusão de catequese", feita pela justaposição de crenças entre os negros e pela fusão dessas crenças pelos mulatos e crioulos, não seriam "mais do que etapas do processo de aculturação, graus do sincretismo, pela maior ou menor percentagem de aceitação, por um grupo religioso, dos traços culturais de outro grupo”. (FERRETTI, 1995, p. 44)

Conforme Ramos, o sincretismo seria o "resultado harmonioso" do "mosaico cultural sem conflito, com participação igual de duas ou mais culturas em contato" (FERRETTI, 1995, p. 45). O “processo harmonioso" em que se deu o sincretismo no Brasil e na Bahia foi uma característica das análises feitas na década de 1930, reforçadas com o mito da "democracia racial", dos anos 1940, 
propagado por Gilberto Freyre e outros pesquisadores. (SAMPAIO, 2000, p. 232)

Entretanto, em estudos posteriores o próprio Ramos revisou o caráter "harmonioso" e "sem conflito" do sincretismo, afirmando que essas características não se aplicariam em processos de colonização, dominação e escravização. Apesar disso, o sincretismo continuou a ser encarado como o resultado de uma aculturação na qual a cultura subordinada adota características da cultura dominante. (FERRETTI, 1995, p. 45)

Contrariando aos médicos-antropólogos que se dedicaram a estudar os negros no Brasil, o sociólogo francês Roger Bastide foi um dos mais influentes desde a década de 1960, nos estudos sobre as religiões afro-brasileiras. Como analisa Sérgio Ferretti, Bastide foi um dos responsáveis pela crítica ao termo sincretismo e por perceber a insuficiência do conceito de aculturação. (FERRETTI, 1995, p. 54)

Buscando rever as armadilhas interpretativas do termo sincretismo, Bastide afirmava que para compreender o "fenômeno de fusão", ou de "penetração de crenças", "simbiose cultural", ou a "química de sentimentos místicos" do sincretismo afro-brasileiro era imprescindível considerar que "o pensamento do negro se move num outro plano, o das participações, das analogias, das correspondências" (BASTIDE apud FERRETTI, 1995, p. 182). Essa interpretação cuidadosa, buscando perceber as sinuosidades das religiões afro-brasileiras, explica como o pensamento de Roger Bastide influenciou por muito tempo as análises sobre as religiões negras no Brasil. Ele entendia o sincretismo como um sistema de equivalências funcionais, de analogias e de participações dessa forma; não haveria uma mistura disparatada de crenças entre o catolicismo e as religiões afro-ancestrais que conviviam juntas, mas, com papéis diferenciados. (SAMPAIO, 2000, p. 233)

Sensível às dualidades e conflitos entre negros $\mathrm{e}$ brancos no Brasil, Bastide não compreendia a capacidade de convivência entre o "dendê e o pai-nosso" dos adeptos do candomblé no Brasil. Um dos pontos de crítica às análises do sociólogo foi o reforço da dicotomia entre as práticas "negras" versus "brancas", isso teria minimizado as reinterpretações feitas por ambos no que tange às práticas religiosas brasileiras. Nem o catolicismo nem as religiões de matrizes africanas permaneceram as mesmas. Bastide, como destaca Ferretti, via dois mundos que se defrontavam dentro do homem que praticava o candomblé; no entanto, esse tipo de conflito não necessariamente existia en- tre os participantes de religiões afro-brasileiras que vivem num duplo espaço de crenças. (FERRETTI, 1995, p. 59-60)

Para a rezadeira Almerinda, que se declarou católica e umbandista, as duas religiões têm seus momentos e lugares demarcados, para ela ser católico "é ter fé em Jesus! Não é ir para a Igreja ficar lá o tempo todo, todo dia, até varrer o pó da Igreja, não! Ser católico é fazer o bem, ter fé em Deus, fazer suas orações ter sua devoção em casa também!" e "ser da Umbanda é ser espírita, com o espírito de Deus nosso Senhor! Só vem pra ajudar o catolicismo. Tudo pra fortalecer!” ${ }^{23}$ A fala da rezadeira aponta justamente para o conjunto norteador das práticas religiosas brasileiras. O catolicismo funciona, para essa rezadeira, como uma crença paralela que complementa a sua cosmovisão social e religiosa.

A ideia limitada de que um purismo religioso africano, principalmente no candomblé, esteve presente na formação religiosa afro-brasileira cai por terra quando nos deparamos com esses casos de coexistência e com a característica agregacionista da mundividência africana. $\mathrm{O}$ reforço da "pureza" da religião dos orixás também foi feito por alguns dos seus representantes e outros intelectuais na década de 1980, que rechaçaram o termo sincretismo. (FERRETTI, 1995, p. 65-66) Tal perspectiva, como alerta Gabriela Sampaio, também não deu conta de compreender as complexidades de um processo, que não se constitui na homogeneidade. Tais análises tomaram o termo cultura como consenso, como se todos numa dada sociedade compartilhassem das mesmas estruturas, não levando em consideração a dinâmica constante de "transformações e os novos significados que os elementos culturais assumem nos diferentes contextos". (SAMPAIO, 2000, p. 234) Nem o candomblé e muito menos o catolicismo permaneceram "puros" como muitos pressupunham.

É necessário perceber que o processo de formação das culturas e das religiões se fez nas constantes trocas e mudanças. Toda cultura muda com o passar do tempo. Um dos grandes problemas que os estudos sobre as práticas culturais tiveram é que ao apresentar a cultura como consenso, como ressalta Hall, "[...] tendemos a pensar as formas culturais como algo inteiro e coerente ou inteiramente corrompidas ou inteiramente autênticas, enquanto que elas são profundamente contraditórias, jogam com as

23 Almerinda Muniz da Paixão, depoimento cedido em 07 nov. 2011. 
contradições, em especial quando funcionam no domínio do “popular”. [...] (HALL, 2009, p. 255-256)

Assim, ao tratar das práticas culturais e da formação religiosa dos sujeitos, é necessário ter em vista, como sugere Stuart Hall, os contextos sociais e materiais específicos de cada tempo e as relações de força entre os grupos que compõem a dialética social. Sem, contudo, perder de vista o processo sempre mutável e cheio de interferências que ajudam a compor as culturas. O termo sincretismo, assim como o termo "popular" indefinem, desqualificam e limitam a compreensão das práticas religiosas vividas pelos indivíduos, sobretudo, porque pressupõem classificações entre o mais e o menos "evoluído", "erudito" ou "puro".

Estar num duplo espaço de crenças foi uma prática adotada por muitos africanos e seus descendentes na África e na diáspora. Para muitos desses sujeitos, a fé cristã serviu/serve como um sistema de crenças paralelo, contribuindo para complementar a vida religiosa. Essa convivência se tornou possível graças à capacidade dessas populações de relacionar a nova religião, a religião do colonizador, a suas formas de compreender o mundo. O catolicismo muitas vezes serviu como mais um instrumento de solução dos problemas temporais, seus ritos e símbolos foram transformados e integrados às visões religiosas e sociais de africanos e seus descendentes pelo mundo. (SWEET, 2007, p. 244)

\section{Considerações Finais}

Carregadas de aspectos culturais, as religiões formadas no Brasil foram traduzidas pelos indivíduos, dentro do conjunto de influências que apresentavam. As trajetórias dos rezadores apresentadas neste artigo, formadas no processo de composição, contatos e trocas, contaram, também, com um alto grau de imprevisibilidade em sua origem. Tomando-as como exemplo, é possível compreender o fenômeno de transformação das experiências religiosas individuais que são, ao mesmo tempo, compartilhadas com outras pessoas que recorrem aos saberes e curas desses rezadores.

Viver no limite maniqueísta entre "práticas de cura do bem" versus "práticas de cura do mal" deu a várias rezadeiras e rezadores a capacidade de estabelecer novas conexões religiosas e disseminar saberes que salvaram ou amenizaram os sofrimentos da vida na zona rural e na cidade de Santo Antônio de Jesus, entre as décadas de 1940 a 1970. Os impasses entre a Igreja Católica e a fé dos rezadores não impediram as reformulações e interpretações do catolicismo e da cura à luz de perspectivas religiosas múltiplas. As estratégias e composições da fé continuarão a se esquivar das tentativas de perseguição religiosa e de qualquer classificação teórica que não considere sua capacidade sempre inesperada de transformação.

Para dar conta dessas relações, é preciso partir de outros referenciais, que tomem essas experiências diferenciadas como ponto de partida. É fundamental que questionemos as supostas bases euro-ocidentais do catolicismo vivido pelas populações negras no Brasil. Precisamos nos voltar para a composição do catolicismo negro de rezadores, benzedores, raizeiros, parteiras dentre outros indivíduos, que possuem bases de pensamento sociorreligioso africano.

\section{Referências}

BEOZZO, José Oscar. Os resultados da discussão historiográfica na CEHILA. In: BRANDÃO, Sylvana. (Org.) História das religiões no Brasil. Recife: Ed. Universitária da UFPE, 2001.

BURKE, Peter. Hibridismo cultural. Tradução: Leila Souza Mendes. Porto Alegre: Unisinos, 2006.

FERRETTI, Sérgio Figueiredo. Repensando o sincretismo. São Paulo: EDUSP; São Luís: FAPEMA, 1995.

GLISSANT, Édouard. Introdução a uma poética da diversidade. Tradução: Enilce Albergaria Rocha. Juiz de Fora: UFJF, 2005.

HALL, Stuart. Notas sobre a desconstrução do "popular". In: SOVIK, Liv (Org.). Da Diáspora: identidades e mediações culturais. Tradução: Adelaine La Guardia Resende. Belo Horizonte: UFMG, 2009. 231-247.

MAINWARING, Scott. Igreja católica e política no Brasil (1916-1985). Tradução: Heloisa Braz de Oliveira Prieto. São Paulo: Brasiliense, 1989.

PIRES, Josivaldo. Adeptos da mandinga: candomblés, curandeiros e repressão policial na Princesa do Sertão (Feira de Santana-BA, 1938-1970). 2010. 215 f. Tese (Doutorado em Estudos Étnicos e Africanos) - Faculdade de Filosofia e Ciências Humanas, Universidade Federal da Bahia, Salvador, 2010.

RODRIGUES, Raymundo Nina. Os africanos no Brasil. 7. ed. São Paulo: Companhia Editora Nacional, 1988. 
SAMPAIO, Gabriela dos Reis. A história do feiticeiro Juca Rosa: cultura e relações sociais no Rio de Janeiro imperial. 2000. 271 f. Tese (Doutorado em História) - Instituto de Filosofia e Ciências Humanas, Universidade Estadual de Campinas, Campinas, 2000.

SANTOS, Denílson Lessa. Nas encruzilhadas da cura: crenças, saberes e diferentes práticas curativas Santo Antônio de Jesus Recôncavo Sul - Bahia (1940-1980). 2005. 230 f. Dissertação (Mestrado) - Universidade Federal da Bahia, Salvador, 2005.
SWEET, James. Recriar África: cultura, parentesco e religião no mundo afro-português. (1441-1770). Lisboa: Edições 70, 2007. 